\title{
Sesonkiäänimaisema kaupungissa
}

\author{
Jouluinen taustamusiikki kalendaarisena koristeluna
}

Meri Kytö

T oulunaika aiheuttaa aistittavan muutoksen ympäri maailman. Pääosin kristillisen kulttuurin piirissä olevissa kaupungeissa kaupallinen ja julkinen tila koristellaan paikallisia perinteitä noudattaen. Näin tehdään yhtälailla esimerkiksi Istanbulissa ja Tokiossa, vaikka niissä ei laajasti harjoiteta joulun uskonnollisia rituaaleja. Suomalaisissa kaupungeissa näkyviä joulukoristeita ovat suuret kuuset toreilla tähtineen, näyttävät valosarjat katujen yllä, tavaratalojen jouluikkunat liikkuvine leluasetelmineen, paperiset lumitähdet koulujen ikkunoissa ja sähkökyntteliköt toimistojen ikkunoissa. Joulusesonki sulkee sisälleen myös itsenäisyyspäivän, Lucian päivän ja uudenvuoden, joilla on omat koristeluperinteensä ja kuvastonsa. Koristelu alkaa näkyä katukuvassa keskimäärin marraskuussa jatkuen loppiaiseen tammikuulle, jolloin kaupungit vievät kuuset pois toreilta ja tavaratalot uudelleenkoristelevat näyteikkunat alennusmyynteihin. Visuaalisen koristelun rinnalla muuttuu myös kaupungin äänimaisema. Lumen narskeeseen, loskan lotinaan ja hiekoitussoran rahinaan alkaa sekoittua toppavaatteiden suhinaa ja niiskuttelua. Sitten marraskuussa erityisesti kaupallinen tila kokee äänellisen muodonmuutoksen: taustamusiikkina alkaa kuulua joulusesonkiin miellettävää musiikkia.

Taustamusiikilla tarkoitan kaupallisissa ja julkisissa tiloissa pääosin taukoamatta soivaa, mekanisoitua musiikkia, jolla on kaupalliseen tuottavuuteen, työnteon edistämiseen tai muun toiminnan tukemiseen liittyvä tehtävä. Taustamusiikkia kaupallisessa ja julkisessa tilassa määrittää myös se, että se on pääosin jonkun muun kuin kuulijan itsensä valitsemaa tai tekemää (ks. Uimonen ja Kytö 2020,48). Mikä tahansa musiikki voi toimia taustamusiikkina. Äänite Bachin "Jouluoratoriosta" voi olla taustamusiikkia siinä missä midi-saksofonilla soitettu cover-versio "Hei kuuraparrasta".

Tässä artikkelissa tutkin jouluisen taustamusiikin kokemista kaupunkitilassa ja sitä, miten se ilmiönä vastaa visuaalisilla elementeillä koristelua. Jouluisella musiikilla kaupungin koristeleminen on oma erityinen kalendaarisesti ajoitettu taustamusiikkikäytäntönsä. Tämä tekee siitä kiinnostavan tutkimuskohteen, koska poikkeuksena se nostaa esiin sitä arkista äänellistä ympäristöä, johon muutoin suhtaudutaan välinpitämättömästi, vältellen tai joka usein jää huomiotta. Jouluinen taustamusiikki on äänellinen ilmiö, jota ei lähtökohtaisesti ole tarkoitettu keskittyneesti kuunneltavaksi toisin kuin esimerkiksi joulukonserttien musiikkia. Kiinnostukseni kohteena on siis "ohikuultu" musiikki. Ohikuulemisen hetkellisestä luonteesta huolimatta kuulija voi liittää siihen samanlaisia merkityksiä kuin mihin tahansa 
musiikkiesitykseen. Merkitys rakentuu ohikuulijan musiikkikulttuuriselle tietämykselle, henkilökohtaisille muistoille ja mieltymyksille. Kiinnostavan jouluisesta taustamusiikista visuaaliseen koristeluun rinnastuvana ilmiönä tekee sen arkinen ja vuosittain toistuva luonne. Tämä kalendaarisesti rakentuva musiikillinen äänimaisema toimii esimerkkinä kaupunkitilan äänellisen arkkitehtuurin rakenteista ja siitä, miten merkityksellistä aikaan sidottu muutos siinä on.

Äänimaisematutkimuksen keskeisiä kiinnostuksen kohteita on ollut kuuntelemisen erilaiset tavat. Tutkimusta on tehty painottaen keskittynyttä kuuntelua, äänen merkityksellistämistä ja sen ymmärtämistä osana kulttuurista viestintää, paikan tuntua, ympäristön muutosta ja yhteisöllisiä tapahtumia. Taustamusiikin tutkimus on sellaisen musiikillisen ympäristön tutkimusta, jota "kukaan ei kuuntele". Taustamusiikkia on äänimaisematutkimuksessa 1960-luvulta 1990-luvulle käsitteellistetty osana meluongelmaa. Ympäristössä nykyisin soivan musiikin vahvasta medioituneisuudesta ja digitaalisen infrastruktuurin mahdollistamasta jokapaikkaisuudesta johtuen ei ole enää tutkimuksellisesti relevanttia, saati kunnianhimoista tutkia taustamusiikkia ongelmallisesti "melusaasteena", jolle altistutaan, tai moralisoinnin kohteena varsinkaan, jos samalla sivuutetaan sen kulttuuriset merkitykset. Suomessa taustamusiikkia on tarkasteltu 1990-luvulta lähtien nimenomaan osana ympäristöä, paikkoja ja tilaa (ks. Järviluoma 1997, 220-221; Kilpiö 2005 \& 2011; Kontukoski 2018; Kontukoski \& Uimonen 2019; Ranta 2005 \& 2006; Uimonen 1999 \& 2018; Uimonen ja Kytö 2020). Tämä tutkimus jatkaa suomalaisen äänimaisematutkimuksen perinnettä ymmärtää taustamusiikki osana ääniympäristöä ja kulttuurisia käytänteitä.

Tutkin taustamusiikkia kontekstisidonnaisesti suhteessa siihen tilaan, jossa musiikkia on kuultavissa. Miellän taustamusiikin tässä yhteydessä äänellisen tilan sisustuselementiksi. Näen, että jouluisen musiikin soittamisessa on kyseessä koristeluntapainen käytäntö, joka liittyy erityisesti juhla- ja myyntisesongin merkitsemiseen äänellä. Kansatieteilijä Kaisu Jaakkola (1977) tuo esiin koristelun erityisesti joulun viettoon keskeisesti liittyvänä tapana. Kodin visuaalista koristelua tutkineen Kari Korolaisen $(2012,11)$ mukaan koristelu on juhlakausiluonteista elementtien lisäämistä ja toistamista, kulttuurisesti kiteytyneitä käytäntöjä ja arjen estetiikkaa. Korolaisen mukaan kansatieteessä ja perinteentutkimuksessa koristelu on nähty usein erityisesti tapakulttuurin juhlatapoihin kuuluvana ilmiönä. Otan lähtökohdaksi Korolaisen ajatuksen koristelun vuodenkierrosta: milloin ja mihin koriste on tapana laittaa esille, milloin se sopii laittaa takaisin pois näkyvistä, ja miten tämä vuosittain toistuva rituaali rinnastuu musiikkiin kaupunkitilassa. Äänimaisematutkimuksessa on myös tutkittu akustisia päivä- ja -vuosirytmejä (ks. Järviluoma ym. 2009), mutta julkisen ja kaupallisen tilan taustamusiikkia ei toistaiseksi olla nähty niiden osana. Pyrin tässä tutkimuksessa osoittamaan tapoja, joilla äänellinen koristelu tehdään kaupunkitilaan, miten se on osa vuodenkiertoa ja miten taustamusiikkia koetaan joulusesongin yhteydessä.

Aineistona käytän vuosien 2019 ja 2020 vaihteessa keräämiäni havaintoja kuullusta jouluisesta musiikista. Aineisto koostuu kuulemishavaintojen keruuaineistosta (ACMESOCS-JouluB 2020) ja omista autoetnografisista äänimaisemahavainnoistani kuuntelupäiväkirjan muodossa (ACMESOCS-JouluA 2020). Aineistoa analysoimalla selvitän, missä, milloin ja millaisissa yhteyksissä jouluista taustamusiikkia kuullaan ja millaiseksi äänelliseksi kokemukseksi 
se mielletään. Aineiston tulkinnan tukena käytän myös tutkimushankkeen' toista aineistoa, palvelualalla työskenteleville suunnattua kyselyaineistoa (ACMESOCS-PAM 2021), jossa esiintyy mainintoja joulusesongin musiikista työympäristössä. Taustoitan aineistoanalyysini kuvauksella joulumusiikista osana taustamusiikkikulttuuria ja selvityksellä siitä, millaiseksi tuotteeksi se on rakennettu. Joulunajan koristelu on vahvasti sidoksissa mainostumisen prosesseihin (ks. Malmelin 2003, 42). Laajemmin medioituneena ilmiönä koristeet ovat usein ominaisuuksiltaan mainonnallisia, eli ne sisältävät kaupallisia viestejä ja tuovat esille brändejä ja tuotteita. Tästä syystä on tärkeää taustoittaa, millaiset musiikkiteollisuuden infrastruktuurit vaikuttavat joulusesongin koettuun äänimaisemaan.

\section{Joulumusiikki taustamusiikkina}

Joulumusiikki on kausimusiikkia. Sitä esitetään, kuunnellaan ja käytetään sesonkiluontoisesti osana vuotuisjuhlia ja tapakulttuuria. Suomalaiseen joulumusiikkiperinteeseen kuuluu olennaisesti musisointi ja yhteislaulut, jotka jalkautuvat julkiseen tilaan esimerkiksi kuoroesityksinä tai katusoittona. Osa tästä elävästä musiikista toimii taustamusiikin tavoin sisustuksellisena ja funktionaalisena elementtinä kauppakeskuksissa. Marraskuulta alkava pikkujoulujen juhliminen sisältää usein myös musikointia (Small 1998), musiikkiin osallistumista kuuntelemalla ja tanssimalla, vaikka musiikin ei ole tapana olla joululaulupainotteista. Joulumusikoinnin perinne Suomessa on vahva. Kouluopetus on institutionalisoinut joulumusikointia 1800-luvulta lähtien. Nykyisin joulunajan musiikkia opetetaan kouluissa, joissa harjoitellut kappaleet esitetään syyslukukauden lopuksi koulun joulujuhlassa. Elävän musiikin lisääntyminen kaupunkitilassa ilmenee eritoten kirkoissa, joissa konserttitoiminta jopa nelinkertaistuu joulukuussa. Vuonna 2019 kirkoissa järjestettiin 4219 konserttia, joista suuri osa on yhteislaulutilaisuuksia (T. Halmeenmäki, Kirkkohallitus, henkilökohtainen tiedonanto, 11.8.2021).

Kausimusiikkina joulumusiikki sisältää historiallisia tyylejä usean vuosisadan ajalta. Se ei ole tyylilajisidonnaista ja siksi sille on vaikea esittää selkeitä äänellisiä tunnusmerkkejä. Ensimmäinen tunnettu joulunajan laulu on Pyhän Ambrosiuksen nimiin laitettu hymni "Veni redemptor gentium" 300-luvulta (Studwell 2011, 2). Vanhimpia vielä nykyisinkin kaupungilla kuuluvia joululauluja ovat Piae cantiones -kokoelman sävelmät 1500-luvulta (ks. Mäkinen 1968), näistä tunnetuimpana "Gaudete", jonka kuorolaulajat tunnistavat alun rytmistä (- - . - . . - - ). Merkittävä vuosisata joululaulujen tuotannossa ja popularisoinnissa oli 1800-luku, jolloin joulunajan lauluja sävellettiin, sovitettiin, käännettiin ja kerättiin Euroopassa ja Yhdysvalloissa runsaasti (Leigh-Choate 2020). Tähän vaikutti osaltaan nuottikustannuksen yleistyminen, josta 1800-luvun aikana muodostui kansainvälinen liiketoimi, sekä ajan populaarimusiikin musiikilliset rakenteet, laulullisuus ja melodisuus, klassis-romanttiset pienmuodot ja kansanmusiikkivaikutteet (ks. Kurkela ja Jalkanen 2003, 25, 29). 1800-luvun alussa Suomessa myös vahvistui tiernapoikaperinne (Pajamo ja Tuppurainen 2004, 298-300) ja myöhemmin 1900-luvun alusta lähtien Lucia-kulkueet lauluineen. 1900-luvulla erityisesti Yhdysvalloissa nousi suosioon maalliset joululaulut. Tämä kehitys vahvistui toisen maailmansodan jälkeen niin, että uskonnolliset joululaulut jäivät radiosoitossa ja levymyynnissä vähemmistöön (ks. Studwell 2011, 2-3). Yleinen tapa kategorisoida joulumusiikkia on järjestää sitä sanoituksen tematiikan ja alkuperän mukaan jouluyön

1 Artikkeli on kirjoitettu osana Suomen Akatemian rahoittamaa Kuuntelun kulttuurit, medioidut äänet ja rakennetut tilat -tutkimusprojektia (ACMESOCS). 
tapahtumista kertoviin uskonnollisiin virsiin ja lauluihin ("Enkeli taivaan"), perinteisiin joulunviettoa kuvaaviin kappaleisiin ("Arkihuolesi kaikki heitä"), leikki- ja tanssilauluihin ("No onkos tullut kesä") sekä kotimaiseen jouluiskelmään ("Joulumaa") ja kansainvälisiin joululauluihin ja -hitteihin ("Winter wonderland").

Joulumusiikin lähtökohtainen uskonnollisuus ja ideologisuus ovat tutkimuksellisesti kiinnostava ominaisuus muutoin neutraaleiksi ja häiritsemättömiksi suunniteltuihin taustamusiikkisisältöihin. Populaarimusiikintutkija Freya Jarman-Ivensille $(2008,118)$ joulumusiikin ideologiset painopisteet näyttäytyvät suurpiirteisinä ajatuksina perheestä, lahjojen antamisesta ja romanttisesta rakkaudesta. Musiikintutkija Todd Decker vie ajatusta joulun musiikillisesta tunnelmasta pidemmälle ajatuksellaan valkoisesta, vihreästä ja sinisestä joulumusiikista. Valkoisessa joulumusiikissa kuvataan joulua kokemuksena ja muistoina, vihreässä ollaan lahjojen parissa ja sininen joulumusiikki käsittelee joulua romanttisena aikana (Decker 2020). Taustamusiikkia ajatellen Deckerin tunnelmaväreihin jaottelu ja Jarman-Ivensin jouluideologinen tematisointi voisivat olla toimivia lähtökohtia, koska näitä kaikkia tunnelmia käytetään kaupallisten ja julkisten tilojen musiikillisessa koristelussa. Toisaalta ne eivät ole täysin ongelmattomia, koska molemmissa tematisoidaan musiikkia pääosin lyriikan sisällön perusteella. Oletuksena on, että kuulija seuraa sanojen merkityksiä. Taustamusiikin tapauksessa tämä ei ole oletettu kuuntelutapa. Molemmat tutkimukset on myös tehty englanninkielisessä kulttuuripiirissä, ja tästä syystä on ymmärrettävää, että kuulijalle englanniksi lauletut (populaari)musiikin kappaleet ovat sanoiltaan ymmärrettävät. Kun tutkimuksen kohteena on pääosin Suomessa olevien kaupunkien äänimaisema, on pidettävä mielessä, että varsinkin joulun aikaan kaupungilla kuuluva musiikki on paitsi englannin-, myös suomen-, ruotsin-, saamen- ja latinankielistä. Monikielisyydestä johtuen ei voida olettaa, että sanat olisivat kaikille kuulijoille samaan tapaan ymmärrettävät. Usein taustamusiikkina käytetään instrumentaalikappaleita, jolloin sanoitus ei kappaletta melodiasta tunnistamattomalle aukea. ${ }^{2}$ Näistä syistä sanoitukseen ja kappaleen tunnistamiseen ylipäätään perustuva kappaleiden jaottelu on hieman epätarkoituksenmukaista, kun tutkimuksen kohteena on taustamusiikki.

Joulunajan selkein äänellinen tunnuspiirre kaupunkiäänimaisemassa on lopulta tietynlainen musiikillinen sointiväri, helinä. Se koristaa yhtä lailla kaupallista tilaa kuin uskonnollisia paikkoja, tonttulakkeja ja kirkkorekiä, ja on merkitsijänä sekä "ilon juhlalle" että "joulurauhalle". Jarman-Ivens kutsuu tätä metallisointista ääntä musiikilliseksi kiilloksi ("musical tinsel", Jarman-Ivens 2008, 115). Decker kutsuu sitä hohteeksi ("glistening timbre"), joka syntyy kellopeleistä, celestoista, triangeleista, sormisymbaaleista ja rekikelloista ja on läsnä lähes jokaisella joulualbumilla toisen maailman sodan jälkeen (Decker 2020). Myös musiikkihistorioitsija Vesa Kurkela (1999) kiinnittää huomiota joulunajan viihdemusiikin kirkkaiden äänien (joita hän kutsuu helinäksi, kilinäksi ja kilkatukseksi) korostuneisuuteen. Toisin kuin Decker, hän selventää sen juontuvan jo 1800-luvulle joulumusiikin kulta-aikaan. Ajalle muodikkaat soitinautomaatit ja kapakkapianot olivat teollistuvan ja kaupungistuvan yhteiskunnan ilmiöitä, joita ei voinut välttyä kuulemasta kaupungeissa kulkiessaan.

Kilinäympäristön yhteisenä piirteenä olivat siten kaupallisuus, huvittelunhalu, urbaanisuus sekä uusi teknologia; ne olivat kaikki 1800-luvun modernin yhteiskunnan tärkeitä määreitä. Sakraalin pyhän

2

Instrumentaalimusiikkia käytetään nimenomaan siitä syystä, että se kiinnittäisi itseensä vielä vähemmän huomiota eikä vahingossa sisältäisi ei-toivottuja viestejä. Englanninkielisen musiikin suosimiselle Suomessa on kauppakeskuksissa mainostekniset syyt. Suomenkieliset puhemainokset erottuvat tällöin paremmin äänivirrasta. (Uimonen 2021.) 
hetken äänestä tuli siten teollistuvan ja kaupungistuvan yhteiskunnan dynaamisimman maallisen tapahtumapaikan keskeinen ilmaisija. (Kurkela 1999, 160.)

Helisevillä äänillä on pitkä historia uskonnollisessa musiikissa pyhän hetken merkitsijänä. Tämä helinä on jäänyt merkitsemään sitä, mitä voisi kirkollisen tilan ulkopuolella kutsua joulun taiaksi.

Mitä joulumusiikkia julkisessa ja kaupallisessa tilassa sitten soitetaan? Kaupungilla kuuluva taustamusiikki rakentuu musiikkiteollisuuden tarjoamilla ehdoilla. Musiikkiteollisuuden näkökulmasta taustamusiikki on tilaan ostettu tuote ja palvelu, jossa kappaleet valitsee palveluntarjoaja. Julkisen ja kaupallisen tilan jouluinen taustamusiikki uusintaa ja tuottaa musiikillisia perinteitä, mutta se tuottaa myös paljon taloudellista tuottoa. Näitä tuottoja tuloutuu sekä musiikkielinkeinolle että vähittäiskaupalle. Taustamusiikki tuottaa tekijänoikeuskorvauksina lähes yhtä paljon kuin radiosoitto tai konsertit ja muut tapahtumat (Teosto avoimuusraportti 2020) ja Gramex-korvauksina tuottajille ja taiteilijoille enemmän kuin radio- ja televisiokäyttö (Gramex avoimuusraportti 2019). ${ }^{3}$ Kyse on siis huomattavasta osasta musiikkiteollisuutta. Joulusesonki tuo myös vähittäiskauppaan merkittävästi lisää liikevaihtoa. Koko vähittäiskaupan arvonlisäverollinen myynti joulukuussa 2019 oli lähes 4,8 miljardia euroa. Keskimäärin myynti kasvaa joulukuussa neljänneksen ja joillakin erikoiskaupan aloilla sekä tavaratalokaupassa se tuplaantuu. (Kurjenoja 2019.) Sosiologi John Schmalzbauerin (2020) sanoin tällaisena Jumalan ja mammonan yhtymäkohtana nykyjoulu merkitsee sekä kirkossa käymisen että vähittäiskaupan vuosittaista huippuhetkeä, jonka johdosta sekä seurakunnat että tavaratalot voivat päättää vuoden plussan puolelle.

Yleisin lähde taustamusiikille on edelleen julkisrahoitteiset ja kaupalliset radiokanavat (Uimonen 2021, 145). Lukuisten vain joulumusiikkia soittavien kansainvälisten nettiradioiden lisäksi kotimaisia vaihtoehtoja ovat joulun ajaksi joulumusiikkiin siirtyvä Nelonen median Radio Aalto (2021 alkaen Me Naiset -radio) ja ainoastaan joulumusiikkia soittava, seurakuntien ylläpitämä ja mainokseton Jouluradio. Verrattuna Radio Aaltoon Jouluradio soittaa määrällisesti enemmän sekä hengellistä että perinteistä suomalaista joulumusiikkia. Tällainen joulumusiikki on myös kuulijoiden suosiossa. Esimerkkinä tästä on listaus Jouluradion "viikon toivotuimmista" joululauluista, jossa näkyy suuri perinteisen ja hengellisen musiikin osuus, iskelmätähtien esittämänä (ks. kuva 1 seuraavalla sivulla).

Taustamusiikkiteollisuuden näkökulmasta radion soittaminen kaupallisessa tilassa on riski, koska musiikkikappaleiden lomassa lähetettävät mainokset ja uutiset voivat tuoda tilaan epätoivottuja mielleyhtymiä, ideologioita ja politiikkaa. Virsien ja hengellisen musiikin soiminen kaupallisessa tilassa on sesongin luoma poikkeus, jota taustamusiikkipalveluissa vahvasti vältellään.

Jos tilassa ei soi radio, on toiseksi yleisin taustamusiikin lähde suoratoisteiset soittolistapalvelut. Listat voi tilata suunnittelupalveluna tai liikkeet voivat koostaa ne itse. Soittolistojen kokoamisesta on tullut ammattimaista ja siihen on näin vakiintunut tiettyjä käytäntöjä.

3 Vuonna 2019 radiosoitto tuotti Teosto-korvauksia 8898265 euroa, konsertit ja muut tapahtumat 8148663 ja taustamusiikki 7465170 euroa (Teosto avoimuusraportti 2020). Vuonna 2019 radio- ja televisiokäyttö tuotti Gramexkorvauksia 8899178 ja taustamusiikki 9024336 euroa (Gramex avoimuusraportti 2019). 


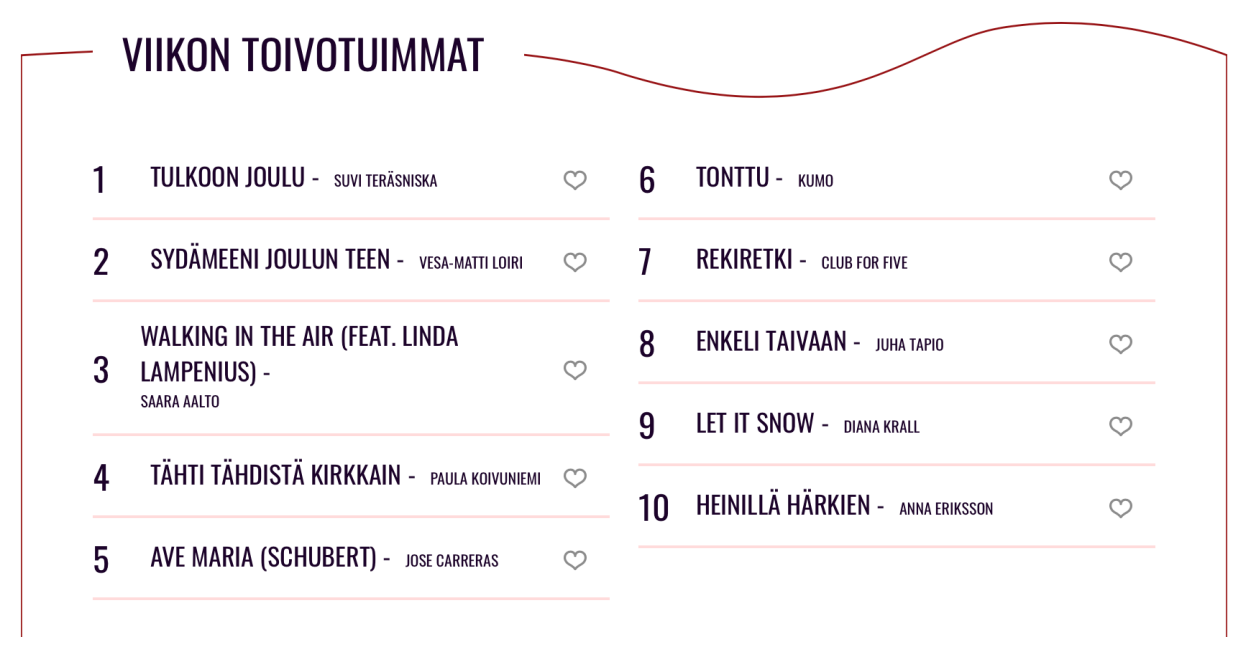

Kuva 1: Jouluradion viikon toivotuimmat kappaleet marraskuussa 2019. Kuvakaappaus Jouluradion verkkosivuilta 15.11.2019.

GT Musiikkiluvat ${ }^{4}$ opastaakin yrityksiä joulumusiikin soittamiseen muistilistalla, jossa kehotetaan tekemään useampi lista rauhallisemmille ja reippaammille kappaleille (GT Musiikkiluvat 2020). He suosittelevat listan laajuudeksi 250-300 kappaletta toistuvuuden ja henkilökunnan kyllästymisen välttämiseksi. Lisäksi he kehottavat yhdistelemään musiikkityylejä ja laulukieliä rohkeasti ("yllättäväkin joulumusiikki ilahduttaa, kun se sopii yrityksesi ja liiketilasi tunnelmaan"). Muistilistasta voidaan lukea tämänhetkisten käytäntöjen ja ammatillisten suositusten pääpiirteet. Liikkeen tehtävänä on kuvitella itselleen tarkoituksenmukainen musiikillinen (joulu)profiili. Tilassa oleva työntekijä taas toimii ikään kuin joulutunnelman tiskijukkana valikoiden tilanteeseen sopivia soittolistoja ja vaihdellen niitä tarpeen mukaan. Soittolistojen käyttö vaatii siis huomattavasti enemmän paneutumista ja suunnittelua kuin jouluradiokanavan valinta, ja sesonki tuottaa siihen omat esteettiset hankaluutensa ("joulumusiikin ei tarvitse olla pelkkää tonttuhumppaa tai joulupuuta"). Soittolistojen valikointi on liiketilan somistamiseen ja muuhun joulukoristeluun verrattavaa työtä.

Jos kaupallisen tilan taustamusiikkia ei valita radiokanavista eikä soittolistoista, se on mitä suurimmalla todennäköisyydellä osa tilattua taustamusiikkituotekokonaisuutta, johon kuuluvat soittolistat, puhemainokset sekä äänentoistotekniikka. Näissä noudatetaan yleistä käytäntöä joulumusiikin määrän kasvattamisessa, mitä lähemmäksi jouluaattoa mennään. Marraskuussa joulumusiikin osuus kappaleista on kymmenisen prosenttia kasvaen adventtien ja joulukauden avajaistapahtumien edetessä 75-100 prosenttiin jouluviikolle (Uimonen 2021, 156). Työntekijöillä, jotka eniten musiikkia kuulevat, ei ole päätösvaltaa soiviin kappaleisiin.

Se, mitä jouluista musiikkia kaupungilla voi kuulla, määräytyy lähtökohtaisesti yllä selvennettyjen taustamusiikkikäytäntöjen ja niihin liittyvien musiikinvalintaprosessien logiikan mukaan. Näillä ei kuitenkaan voida vastata kysymykseen siitä, millaisena kyseinen musiikki kuullaan tai miten ohikuulija sen merkityksellistää, vaan ainoastaan hahmottaa kehykset

4 GT Musiikkiluvat Oy on kahden tekijänoikeusjärjestön, Teoston ja Gramexin vuonna 2016 perustama yhteisyritys, jonka tehtävänä on myydä taustamusiikinkäyttölupia sekä välittää musiikin käytöstä kertyneet varat musiikin tekijöille, esittäjille, tuottajille ja kustantajille. 
asiayhteydelle. Oletukseni on, että jouluista taustamusiikkia koetaan paljon monipuolisemmin kuin mitä taustamusiikkia tarjoavat ovat funktionaalisesti suunnitelleet.

\section{Metodologinen lähestymistapa kausimusiikkiin kaupunkiympäristössä}

Äänimaisematutkimuksellisesti taustamusiikki lukeutuu niin kutsuttuihin perusääniin. Niillä tarkoitetaan ympäristön ääniä, jotka jatkuvaluonteisina toisteisuudessaan ja muuttumattomuudessaan sekä yllätyksettömyydessään jäävät viestinnällisesti huomiomme sivuun (Truax 2001). Niitä ei siis tarvitse seurata uuden tiedon saamiseksi. Tämän tyyppisiä ääniä ovat esimerkiksi ilmastoinnin humina ja puheensorina kahvilassa. Perusääni muuntuu hetkellisesti signaaliksi, kun sen viestinnällinen sisältö muuttuu. Jouluinen taustamusiikki saakin osakseen huomiota juuri tästä syystä, muutos "tavan taustamusiikista" joulumusiikkiin usein noteerataan, vaikka ei osattaisikaan tarkemmin kertoa, millaista tilaan kuuluva taustamusiikki ennen muutosta oli. Kun ääni on huomioitu ja todettu toisteiseksi, se vaipuu usein takaisin perusäänen tasolle "ei-kuunneltavaksi" ääneksi. Musiikin- ja äänimaisematutkija Ola Stockfelt kutsuu tällaista huomion pois siirtymisen taitoa kuulematta jättämiseksi ("borthöra", Stockfelt 1994, 20; ks. Uimonen 1999). Ääniympäristön tutkimuksessa onkin pitkään teoretisoitu huomion ja distraktion vaihtelevuutta muun muassa aktiivisen kuuntelemisen ja passiivisen kuulemisen käsitteellisen eronteon avulla (Kassabian 2013). On tärkeä huomata, että jokaisessa ääniympäristössä on samanaikaisesti sekä aktiivisen että passiivisen kuuntelun kohteita. Kyse on huomion painotuksen vaihtelevuudesta. Tämä painotusvaihtelun ymmärtäminen on keskeistä taustamusiikin kokemuksessa, joka kaupunkikitilassa on usein päälllekkäisten ja toisiinsa sekoittuvien musiikillisten äänilähteiden kuulemista.

Muun muassa tästä kuulematta jättämisen syystä taustamusiikin kulttuurinen tarkastelu vaatii osakseen monipuolista metodologista otetta ja ilmiön laajaa käsitteellistä hahmottamista, jotta soivaa todellisuutta ja sen kokemista voidaan tutkimuksellisesti lähestyä. Taustamusiikin tutkimista varten olen kehittänyt aineistonkeruumenetelmää, jota kuvaan äänitilan havainnoinnin talkoistetuksi keruuksi. Olemme kokeilleet menetelmää pienimuotoisesti tutkimushankkeessa Joensuun keskustassa soivan taustamusiikin kartoituksessa (Uimonen ja Kytö 2020, 58-62), ja menetelmää kehitetään edelleen tutkimushankkeen tulevassa musiikillista kaupunkitilaa laajemmin käsittelevässä osiossa. Toisin kuin esimerkiksi perinteentutkimuksessa ja äänimaisematutkimuksessakin käytetty kirjoituttamiseen perustuva muisti- ja kokemustietokeruu (ks. esim. Pöysä 2015; Järviluoma ym. 2006; Uimonen ym. 2017), tämä keruu oli kuulohavaintojen raportoinnin talkookutsu. Tarkoituksena oli kartuttaa Luonto-Liiton järjestämän Kevätseurannan tapaan aineistoa joulusesongin musiikillisesta etenemisestä. Talkoistamisella tarkoitetaan sitä, että tehtävä annetaan ratkaistavaksi ennalta määrittelemättömälle joukolle verkossa lähetettävän kutsun avulla. Ohjeistus talkoisiin, jotka olin nimennyt Joululaulubingoksi, oli muotoiltu seuraavasti: ${ }^{5}$

Jos haluat osallistua bingoon ja auttaa minua, tee näin kun törmäät joululauluun:

1. Tunnista kappale (käytä apuna Shazam tai SoundHound -sovellusta jos mahdollista) ja kirjaa ylös kuuntelupaikka.

2. Lähetä tiedot minulle: osoitteeseen [sähköpostiosoite]

$5 \quad$ Keruuilmoitus on kokonaisuudessaan luettavissa kotisivultani, https://merikyto.net/2019/10/31/ merin-joululaulubingo/ 
- tai tämän postauksen alle kommenttina

- tai risuaidalla \#joululaulubingo Twitteriin

- tai Messengerissä

Kuvakaappaus äänitteentunnistussovelluksen paljastamista albumitiedoista olisi plussaa! Lisään sitten lähettämäsi tiedot kalenteriin (nimimerkillä halutessasi) ja päivän postaukseen tänne sivuille." (Joululaulubingo 2020.)

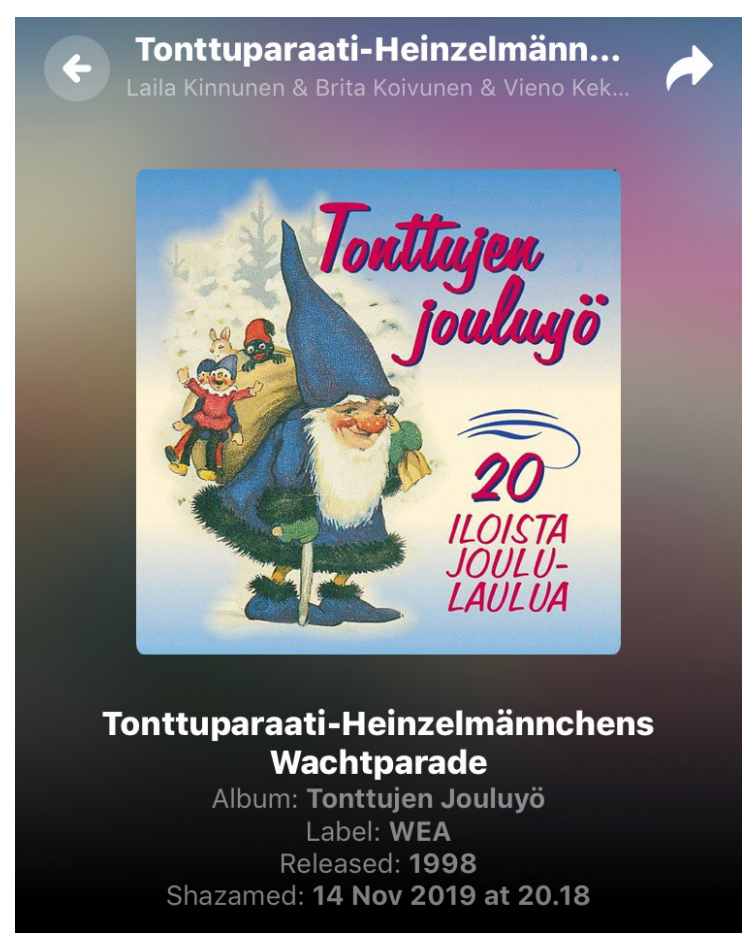

Kuva 2. Esimerkki musiikintunnistussovellus Shazamin tarjoamista tiedoista.
Tiedotin keruusta ja sen tutkimuksellisesta taustasta kotisivuni lisäksi toistuvasti sosiaalisessa mediassa, kuten tutkimushankkeen Twitter-tilillä sekä Facebookin vilkkaassa Tampere-ryhmässä. Pikaviestimillä minulle henkilökohtaisesti lähetettyjen viestien ja keskustelunavausten alla olevien kommenttiketjujen lisäksi löysin osallistujien omissa profileissaan julkaisemat havainnot antamallani aihetunnisteella \#joululaulubingo.

Raportointitalkoisiin osallistui omilla havainnoillaan 49 henkilöä 129 ilmoituksella (ACMESOCS-JouluB 2020). Havainnot ovat pääosin pikaviestin mittaisia muutaman sanan tai lauseen raportointeja, joissa ilmoitetaan kuultu kappale, paikka ja kellonaika sekä näiden lisäksi usein saatteena oli kuuntelukokemuksen kuvailu ja kuvakaappaus äänitteentunnistussovelluksesta (ks. kuva 2). Eri kanavissa (Facebook, Messenger, Twitter, WhatsApp, SMS) välitetyt ilmoitukset noudattivat pääosin yllä mainittua ohjeistusta rakenteeltaan ja sisällöltään. Ilmoitusten saapumisten ajankohdista päättelen, että niistä suurin osa on kirjattu älypuhelimeen ja lähetetty lähes samanaikaisesti havainnointilanteesta. Tätä pidän huomattavana menetelmällisenä etuna perusäänten tutkimuksessa, koska mitä luultavimmin havainto jäisi raportoimatta, jos viestintäväline ei olisi käden ulottuvilla ja olisin pyytänyt reflektoimaan havaintoja monisanaisemmin. Yksinkertaiseen raportointikutsuun oli helppo naputella vastaus keskellä arjen muita toimia.

Tämän keruun lisäksi dokumentoin omaa arkeani autoetnografisen äänimaisemahavainnoinnin keinoin. Äänimaisematutkimuksessa usein käytetty aistietnografinen ja tässä tapauksessa myös autoetnografinen menetelmä on kirjoittaa äänipäiväkirjaa, johon kootaan säännöllisesti havaintoja ja huomioita arjen ääniympäristöstä (Vikman 2007; Kytö 2011). Äänipäiväkirja autoetnografisena aineistona tarjoaa verrattain yksityistä ja yksittäistä ymmärrystä "yleisestä", mutta on oiva menetelmä keskityttäessä pieniin, arkisiin ja tavanomaisiin aiheisiin (ks. Uotinen 2010, 179, 186), jota joulusesongin ääniympäristössä tapahtuvien muutosten tutkiminen on. Tein päivittäin merkinnät kaikesta kaupallisessa tai julkisessa tilassa kuulemastani jouluiseksi mieltämästäni musiikista marraskuulta tammikuulle, yhteensä 71 päivän ajan (ACMESOCS-JouluA 2020). Tein havaintoja myös systemaattisemmin äänitettyjen kuuntelukävelyiden muodossa kotikaupunkini Tampereen kauppakeskuksissa ja joulutoreilla. Kielellisten kenttämuistiinpanojen rinnalla kuuntelukävelyäänitysten 
tarkastelu jälkeenpäin osoittautui hyödylliseksi. Kenttäpäiväkirjoihin merkitsemättä jääneet äänimaisemalliset itsestäänselvyydet tai tilanteessa epähuomioon jääneet yksityiskohdat oli helppo tarkistaa nauhoituksesta. Käytin havainnoidessani hyväkseni tallenteentunnistussovellusta (Shazam) kuulemieni kappaleiden tunnistamiseksi. Julkaisin supistetut koosteet havainnointimerkinnöistä julkisena tutkimuspäiväkirjana päivittäin verkkosivuillani, josta ne ovat edelleen luettavissa (Joululaulubingo 2019).

Yhteensä aineistoni koostuu 266 havainnosta ja ilmoituksesta, joista 213 on jouluiseen musiikkiin "törmäämistä" ja 53 ilmoitusta siitä, että ei ole vielä kuullut kaupungilla joulumusiikkia kyseisenä sesonkina. Törmäysilmoituksista 25 ilmoitusta koski elävää musiikkia ja loput tallenteita. Suurimmasta osasta tallenteita ilmoittaja kertoi tunnistavansa kappaleen. Esittäjien tunnistaminen oli hankalampaa, mutta monesti siitä oli esitetty laulajan äänensävyn tai kappaleen tyylilajin perusteella arvaus. Musiikintunnistussovelluksia oli käytetty kappaleiden kuulonvaraisen tunnistamisen apuvälineenä. Ne eivät kuitenkaan olleet ongelmattomia, koska usein musiikin tulee soida riittävän erottuvasti ja voimakkaasti muusta äänimaisemasta, jotta sovellus pystyy sen tunnistamaan. Toinen syy sovellusten ongelmiin on, että vaikka niiden tietokannat ovatkin mittavat, ne kattavat vain julkaistua musiikkia, eivät esimerkiksi elävän musiikin tallenteita televisiolähetyksistä, mainosmusiikkia tai niin kutsuttua katalogimusiikkia. ${ }^{6}$ Suoratoistopalveluissa julkaistuista tallenteista kokoamani 169 kappaleen soittolista on lukijan kuunneltavissa Spotify-palvelussa. ${ }^{7}$

Vuoden 2019 joulusesongin lisäksi keräsin vastaavaa aineistoa jouluna 2020, mutta tämä aineisto on koronapandemian johdosta huomattavasti suppeampi ja käsittää pääosin omia huomioitani musiikillisista poikkeuksista. Käytän näitä huomioita kuitenkin hyväkseni artikkelin diskussio-osuudessa osoittaakseni tiettyjen musiikillisten perinteiden sitkeyttä ja muuntautumista ja kuvatakseni taustamusiikillisia poikkeuksien poikkeuksia.

Tätä kahdesta osasta koostuvaa, mutta verrattain samantyyppistä havainnointiaineistoani voi pitää kokeellisena summana perinteisimpiä menetelmiä. 1960-luvulla kehitetty äänipäiväkirja- ja kuuntelukävelymenetelmä tuottavat niin kutsuttua korvintodistettua tietoa alueista ja paikoista (Järviluoma ym. 2009). Näihin lisättynä talkoistettu havainnointi muistuttaa 1930-luvun massahavainnoinnin päivittäisraportteja (day-survey). Voisi jopa arvella, että äänimaisemamenetelmät olisivat saaneet tästä varhaisesta antropologiasta vaikutteita. Massahavainnoinnilla tuotetun aineiston fragmentaarisuus mahdollistaa sen hahmottamisen kollaasina: sen sijaan, että irrallisista elementeistä kasattaisiin merkityksellinen ja ratkaistu kokonaisuus, kollaasi tarjoaa kerronnallisesti ristiriitaisen materiaalien suman (Highmore 2002, 94-95). Vaikka tämä tutkimuksen aineisto ei ole lähelläkään massahavainnoinnin mittakaavaa, on se luonteeltaan samankaltaista ja tiedontuottamisena yhteistoimintaa.

Tämän kokeellisen aineiston fragmentaarisuus tulee ottaa huomioon tulkintoja tehdessä. Aineiston tuottamiseen osallistuneet henkilöt eivät muodosta edustavaa ryhmää, jonka havainnoista voisi päätellä mitään yleistettävää joulusesongin etenemisestä, eikä yksittäisten pikaviestien perusteella pysty piirtämään selkeärajaista ajallista karttaa jouluisen musiikin noususta ja laskusta kaupunkiympäristössä. Ne ovat pikemminkin näyte partikulaarista,

$6 \quad$ Katalogimusiikki tai tuotantomusiikki on pääosin av-tuotantoihin taustamusiikiksi tehtyä ja tarkoitettua musiikkia. Katalogimusiikin tallennusoikeus eli käyttölisenssi ostetaan sitä myyvältä yritykseltä. Taustamusiikiksi soveltuvaa katalogimusiikkia voi ostaa esityskäyttöön, vaikka kahdeksan tunnin äänitteen kertakorvauksella. 
eräänlaisesta etäryhmätyöstä, jonka avulla voidaan esittää huomioita joulun musiikillisista tiloista aistinvaraisiin kokemuksiin tukeutuen. Aineiston kerryttämiseen ja viestimiseen on selkeästi vaikuttanut myös tuttuus: kaikki minulle henkilökohtaisesti viestineet olivat henkilöitä, jotka tunsin entuudestaan. Tämä asettaa aineiston selkeästi julkista havainnointipäiväkirjaani tukevaksi ryhmäponnistukseksi, eräänlaiseksi kaksi kuukautta kestäneeksi tutkimukselliseksi työpajaksi, jossa kerätään tietoa joululauluhavainnoista samanaikaisesti eri paikoissa.

\section{Jouluisen taustamusiikin kokemisen tapoja}

Olen eritellyt sekä talkooaineistosta että kuuntelupäiväkirjoistani neljä toistuvaa kokemuksellista teemaa, joilla vastaan kysymyksiin jouluisen taustamusiikin kokemisesta kaupunkitilassa ja sen koristelunomaisesta kausiluonteesta. Nämä teemat ovat 1) kokemus törmäämisestä ja tarttuvuudesta, 2) alkaminen, täystunnelma ja loppumisen ennakointi, 3) vältteleminen ja välttelyn pelillistäminen sekä 4) tilallinen jokapaikkaisuus.

\section{Kokemus törmäämisestä ja tarttuvuudesta}

Heti aineistonkeruun alussa osallistujat nostivat esille kysymyksiä tehtävänannosta ja siinä mainitusta musiikkiin "törmäämisestä". Kuinka tahattomasti ohikuullulle musiikille tuli altistua? Kuinka tarkasti kuullun äänen tuli olla joululauluksi tunnistettua? Mitä tarkoitetaan "kaupungilla"? Onko kauppakeskuksen keskusradion puhemainoksen taustalla kuultu rekikello joulumusiikkia? Nämä olivat kysymyksiä, joita jouduin myös itse arjen tilanteissa punnitsemaan. Sen sijaan, että olisin ohjeistanut keruuta tarkemmin, annoin osallistujien itse päättää, minkä he kokivat joulumusiikkiin törmäämisenä. Ainoana selkeänä poisrajauksena pidin sellaisen musiikin, jota kohti mennään aktiivisesti, esimerkiksi pääsylipulliset konserttitapahtumat, joulurauhanjulistuksen, itse soimaan valitun äänitemusiikin ja oman soitto- tai lauluharrastuksen.

Se, minkä osallistujat kokivat törmäämisenä, on hyvin monipuolista ja sitä tapahtui monenlaisissa tilanteissa ja paikoissa. Minulle ilmoitettiin joululaulujen laulamisesta kotona, töissä, harrastustiloissa ja kadulla. Marraskuun ensimmäisenä päivänä eräs osallistuja kertoi, että henkilöstöravintolassa "joku istuu epävireisen pianon ääreen ja soittaa hapuilevasti säkeistön" joululaulua "Jouluyö, juhlayö". Marraskuulta alkaen ilmoitukset koululaisten ja päiväkotilasten laulamisesta kotona lisääntyivät. Lapset harjoittelivat tulevaa jouluesitystä varten ja laulut kulkeutuivat hyräilyinä ja lallatteluna päiväkodista ja koulusta kotiin. Samoin elävä joulumusiikki lisääntyi tapahtumissa ja tilanteissa, joissa taustamusiikki muutoin oli järjestetty äänittein. Kaupungilla järjestettiin ravintoloissa joulukaraokea. Kuntosaleilla oli joulutaustamusiikin mukaan poljettavan spinningin lisäksi "Kauneimmat joululaulut konserttivenyttelyjä", laulaja-kosketinsoittajan säestyksellä. Kuoroja esiintyi Helsinki-Vantaan lentoasemalla joulupukkihahmon ja tonttuja kera.

Aineiston perusteella voi tulkita, että äänellinen joulusesonki alkaa vaivihkaa tarttuvasta musikoinnista. Joulun traditioon kuuluva musiikin esittäminen ja laulaminen vaikuttaa siten, että joulutunnelma tarttuu enemmän ja vähemmän tahallisesti kaupunkilaisten kesken. Melodioiden tuttuus ja toistuvuus aiheuttaa sen, että sävelmät ja sanat voivat jäädä mieleen pyörimään. Tällöin ne ikään kuin ottavat enemmän tilaa mielestä kuin sen ajan mitä kappaletta itse asiassa kuulee, joka saattaa olla hyvinkin lyhyt aika, muutama sekunti. 
Joulusesonkiin myönteisesti suhtautuva saattaa innostuksissaan työpaikalla tai harrastuksissa vihellellä tai hyräillä. Joulusesonkiin kielteisesti suhtautuva saattaa kokea tämän voimakkaammin kuin viheltäjä saattaisi odottaa.

Musiikin tarttuvuus muistuttaa kokemuksellisena ilmiönä musiikkisosiologi Tia DeNoran (2000, 149-150) käsitystä rinnakkaissubjektiivisuudesta (engl. co-subjectivity). Arkipäivän musiikkikulttuuria tutkinut DeNora tarkoittaa tällä sitä, miten ihmiset voivat kokea ja esittää samanlaisia tuntemuksia ja toimintatapoja suhteessa ulkopuolisiin (kuten musiikin tarjoamiin) parametreihin. Tällainen rinnakkaissubjektiivisuus eroaa intersubjektiivisuudesta eli subjektien välisyyden käsitteestä, joka edellyttää kokijoiden välistä dialogia, refleksiivisyyttä ja merkitysten yhdessä tuottamista. Sitä vastoin rinnakkaisubjektiivisuus on seurausta yksilön itsensä asettumisesta refleksiiviseen suhteeseen ympäristön ja sen materiaalisuuden kanssa. Hyräily ja viheltely on tällaista usein epähuomiossa itselle tuotettua musiikkia, jossa ei niinkään ole intersubjektiivista ulottuvuutta, mutta sen sijaan voimakas rinnakkaissubjektiivisuuden taso.

Musiikin kuulemisen hetkellisyys ja ohimenevyys aiheutti taustamusiikin raportoinnissa hankaluuksia. Facebookin kautta lähetetyissä ilmoituksissa todettiin, että jouluista musiikkia oli kuulunut, mutta muistijälki siitä, mitä se tarkemmin oli ollut, oli päivän mittaan haihtunut.

\footnotetext{
"Kuulin eilen koulun käytävällä ensimmäisen joululaulun nuorison kännykästä. Kappale oli tuttu, mutta enhän minä sitä enään muista." (18.11.2019 ACMESOCS-JouluB 2020)

"I think Akateeminen had Xmassy stuff going this morning as well." (19.11.2019 ACMESOCS-JouluB 2020)
}

Kappaleet eivät jättäneet vahvaa muistijälkeä, mutta joulu merkityksenä oli tunnistettu. Ilmoitusten lähettäminen oli myös epäröivää, vaikka teknisesti se oli oletetusti helppoa mobiilia pikaviestintää. Epäröinnin voi päätellä johtuvan juuri tilanteen lyhytkestoisuudesta ja oletetusta merkityksettömyydestä. Tällaisissa havaintoa tapailevissa ilmoituksissa joulumusiikki ilmenee pienenä elementtinä muun äänimaiseman seassa, ja se ei vielä kerro sesongin alkamisesta vaan ennakoimisesta.

\section{Alkaminen, täystunnelma ja loppumisen ennakointi}

Aikaisimmat havainnot jouluisasta äänitemusiikista aineistossa ovat 8. marraskuuta Helsingistä, baarin vessasta. Suurin osa ilmoituksista ja havainnoista ajoittuu jouluviikolle, jolloin oletettavasti useat aineistonkeruuseen osallistuneet (kuten minäkin) tekivät jouluostoksensa. Joulunpyhät päättää kristillisen kalenterin mukaisesti loppiainen eli 6. tammikuuta. Kaupallinen joulusesonki vaimenee vaihtelevasti joulupäivän jälkeen tammikuun alkuviikoilla. Viimeisin jouluinen taustamusiikkihavainto aineistossa on 4. tammikuuta Tampereen pääkadulla, Sokoksen jouluikkunan edestä. Taustamusiikillisen sesongin päättyminen ei siis ole täysin kaupallisen sesonkikalenterin mukainen.

Kysyessäni marraskuun 19. päivä Tampere-ryhmässä, joko joululauluja on kuulunut, sain vastaukseksi "kyllä" kaupoista (Ikea, Tokmanni), ravintoloista, kahviloista ja huoltoasemilta (ABC). Kolmasosa kommentoijista ei ollut vielä kuullut joululauluja, painottaen kommenteissaan sekä asian mieluisuutta että sesongin alkamisen odottamista: 
"En ole vielä kuullut mutta odotan toiveikkaana." (19.11.2019 ACMESOCS-JouluB 2020)

"Toivottavasti ei edes ala soimaan missää joululaulut" (19.11.2019 ACMESOCS-JouluB 2020)

Itse huomasin pysähtyväni kuuntelemaan sellaisia tilanteita, joissa olisi voinut kuulua joulumusiikkia. Loka-marraskuussa jouduin myös miettimään useaan otteeseen, oliko kuulemani musiikki jouluista ja miten itse ymmärsin äänelliset merkitykset. Parkkihallissa kävelin hallin toiseen päähän, jotta pääsin lähemmäksi ovensuussa olevaa kaiutinta. Sen alle päästyäni erotin musiikista myös sanat. Varmistin sovelluksella, että kyse ei sittenkään ollut joulumusiikista (kappale oli Jay Collins and the Kings county band'in "My dreams came back"). Samoin joogatunnilla mietin yhden kappaleen kohdalla, josko se oli poimittu jouluaattoisin televisiossa esitettävästä "Lumiukko"-animaatiosta. Päädyin lopulta siihen, että ei ollut. Apunani ei tuona hetkenä ollut puhelinta sovelluksineen.

Kaupallinen joulu ja joulusesonkiin liittyvä koristelu alkoi varsinkin ostoskeskuksissa näkyä jo lokakuussa vahvistuen marraskuun neljännen torstain jälkeisenä perjantaina. Tämä Yhdysvalloissa vähittäiskauppojen joulusesongin avauspäivänä tunnettu Black Friday on Suomessakin tullut tutuksi joulusesonkia edeltävänä alennuspäivänä. Marraskuun lopulta alkaen ilmoitettiin havaintoja täydestä sesongin käynnistymisestä äänimaiseman osalta. Täyskoristelu äänin ja visuaalisin koristein vastasi täystunnelmaa eli kokemusta siitä, että joulusesonki on vahvasti läsnä ympäristössä:

\footnotetext{
"Äsken oli Helsingin rautatieasemalla siellä Pullmanissa ihan täysi hööki päällä! Winter wonderlandista Petteri punakuonoon. Sekä hissimusaversiona että laulettuna." (19.11.2019 ACMESOCSJouluB 2020)

"Turun Walossa oli tänään joulumusat, joulukoristeet, glögit ja henkilökunnalla ironiset jouluneuleet;-)." (19.11.2019 ACMESOCS-JouluB 2020)

"Aseman aulan taustamusiikki on myös päivitetty sisältämään kulkusten kilinää ja muita jouluisia ääniä" (23.12.2019 ACMESOCS-JouluB 2020)
}

Samaan aikaan moni myös raportoi tasaisesti, että ei ole ("vieläkään") kuullut yhtään joulumusiikkia kaupungilla kulkiessaan. Tästä voi päätellä, että joulutaustamusiikin kokeminen ei ole kaikille yhtä itsestään selvää.

Sesongin viimeisen kappaleen kuulemisesta on hankalampaa ilmoittaa, ellei kuulemastaan ollut pitänyt äänipäiväkirjaa. Tästä ymmärrettävästä syystä ilmoitukset joululaulujen kuulemisesta jouluaaton jälkeen loppuivat. Äänimaiseman jouluisten elementtien hiipuminen, helinän ja kilinän himmeneminen, kävi oman äänipäiväkirjani mukaan nopeasti. Johanneksen päivän eli 27.12. jälkeen en kuullut missään muualla jouluista taustamusiikkia, paitsi jo mainitun Sokoksen jouluikkunan edessä. Viimeiset joulumusiikkiin liittyvät asiat näin pääkirjasto Metson musiikkiosastolla 9.1., jossa oli vielä esillä hyllykyltti joulumusiikille, mutta nuotit ja levyt oli siirretty jo pois, kirjastonhoitajan arvion mukaan kaksi päivää sitten. Joululehdet olivat vielä koostetusti esillä lehtiosastolla. Ne olisi muuten jo siirretty varastoon, mutta varastotila oli kirjastonhoitajan mukaan sen verran täynnä, että "niitä ei vielä mahdu pakkaamaan takaisin" (ACMESOCS-JouluA 2020). 


\section{Vältteleminen ja välttelyn pelillistäminen}

Jouluisan taustamusiikin ympärillä käytävä julkinen keskustelu on elävää, kommentoiden vuodesta toiseen ajoitusta, musiikin valintaa ja toistuvuutta, voimakkuutta ja väliaikaisia PA-ratkaisuja. Itse suhtauduin positiivisesti joulumusiikin lisääntymiseen ympäristössäni ja oletin ilmoitukseni aineistonkeruusta olleen neutraali, mutta moni ilmoitus tuli minulle huumorilla sävytettynä. Monissa oli mainittu myös reaktio musiikin kuulemiseen. Tampereella oli raportin mukaan juostu joulutorilla kuuluvaa "Nissepolkkaa” karkuun.

\footnotetext{
"Alakouluikäiset Tiernapojat toivottavat topakasti huutaen onnelliista ja hyvää jouluaaa. Juoksen äkkiä paikalta pois." (28.11.2019 ACMESOCS-JouluB 2020)

"Ahh.. Käynti Ikeassa.. Tunnistin joulumusiikin.. aargh.. liian pitkä matka pakoon.." (19.11.2019 ACMESOCS-JouluB 2020)
}

Joululauluihin törmääminen tuntuu tuottavan kaupunkitilassa vielä vahvempia tuntemuksia kuin arkipäiväisempi taustamusiikki. Joulusesongin alkaminen liian aikaisin ja tämän kokeminen paitsi musiikillisten tunnelmien toisteisena tuputtamisena ja kuluttamiseen kannustamisena tuottaa tietynlaista jouluisen taustamusiikin paheksumisdiskurssia.

Yksi joulutaustamusiikin toisteisuutta ironisesti esille tuova sesonki-ilmiö on peli, jonka tarkoituksena on olla kuulematta Wham!-yhtyeen "Last Christmas"-kappaletta ennen jouluaattoiltaa (ks. kuva 3).

Kyseisen kappaleen välttelemisestä on tehty leikki. Jos kappaleen jossain kuulee, on hävinnyt leikissä ja tästä tulee kertoa sosiaalisessa mediassa tunnisteella \#whamageddon. Kappaleen soittamattomuus on toiminut myös mainoksena anniskeluravintoloille. Helsingissä mainostettiin tapahtumaa Lucian päivälle (Ny Tid'd glöggmingel), jossa luvattiin olla soittamatta

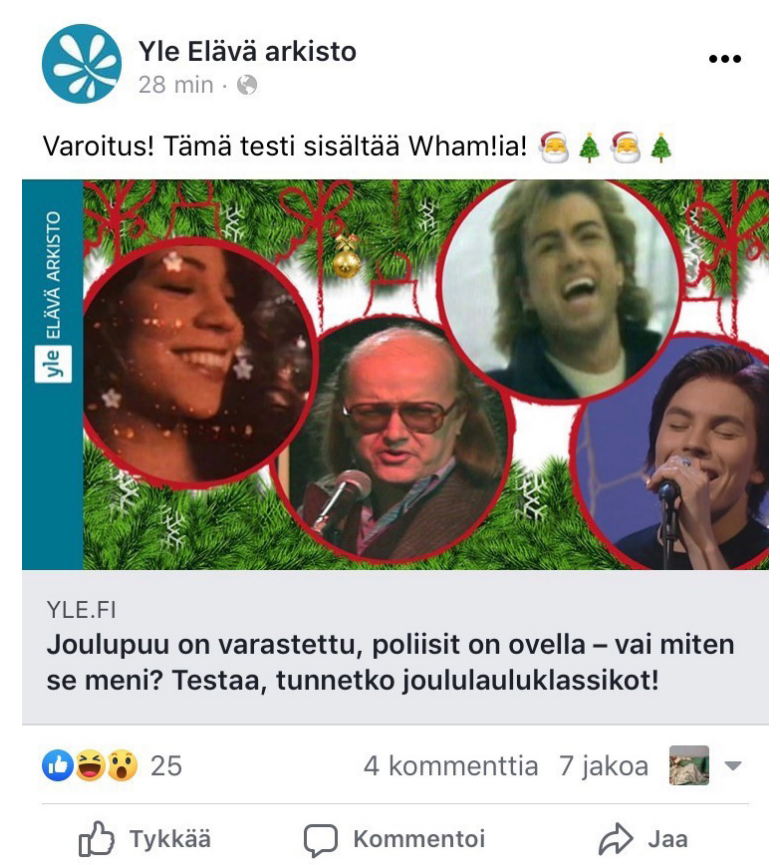

Kuva 3: Kuvakaappaus Yle Elävän arkiston Facebook-sivulta. Julkaisun saatesanat varoittavat, että jutun testi sisältää "Last Christmas"-kappaleen. 
kyseistä kappaletta. Yksi kuudesta raportoinnista tämän pelin tiimoilta tuli marraskuun lopussa Pasilan Mall of Tripla -ostoskeskuksesta:

"Not even December yet and it's \#whamageddon @malloftripla \#helsinki. Toivottavasti eka ja vika osallistuminen \#joululaulubingo on" (30.11.2019 ACMESOCS-JouluB 2020)

Suomalainen vastine leikille vuonna 2019 oli \#loirigeddon, jossa pyrittiin olla kuulematta Vesa-Matti Loirin esittämänä kappaletta "Sydämeeni joulun teen". Pelissä ennakoitiin toistetuinta ja jokapaikkaisinta suomalaista joululaulua. Gramexin (2020) tietojen mukaan "Last Christmas" oli kaupallisten radioiden soitetuin joululaulu Suomessa vuonna 2019 (902 soittokertaa radiossa, kuusi mainintaa aineistossa). Toiseksi soitetuin kappale oli Mariah Careyn "All I Want For Christmast Is You" (781 soittokertaa radiossa, neljä mainintaa aineistossa). Kolmantena ja ensimmäisenä kotimaisena kappaleena oli Vesa-Matti Loirin "Sydämeeni joulun teen" (587 soittokertaa radiossa). Runsaasta radiosoitosta huolimatta aineistossa Loiria ohikuullutta ei ollut ketään vuonna 2019.

\section{Tilallinen jokapaikkaisuus}

Yksi taustamusiikin kokemuksellisista ominaisuuksista on musiikin jokapaikkaisuus (Kassabian 2013, xi, 1). Jokapaikkaisuus tarkoittaa myös, että joulumusiikki saattaa kuulua jostain muusta tilasta, missä itse on. Tällaisia esimerkkejä aineistossa olivat ilmoitukset, joissa kuvailtiin joulumusiikkia kuuluvaksi jostain ulkopuolelta, kuten asunnon alakerrasta tai työhuoneen ikkunan läpi.

\footnotetext{
"Meidän alakerrassa on siis [- -] seurakuntasali jossa parikin laatukuoroa treenaa parina iltana viikossa, sieltä niiitä joululauluja tulee!" (19.11.2019 ACMESOCS-JouluB 2020)

"Ikkunan läpi kuuluu Harjun tornista kaupungin joulunajan iltasoitto eli "Hiljaa, hiljaa joulunkellot kajahtaa" (25.11.2019 ACMESOCS-JouluB 2020)

"Sori Taproom (baari) Helsingin Kaisaniemessä soittaa vessojensa aulassa kissojen naukumia joululauluja." (8.11.2019 ACMESOCS-JouluB 2020)
}

Kissojen naukumien joululaulujen kuuleminen julkisen vessan aulassa on mahdollisesti absurdein esimerkki taustamusiikin tungettelevuudesta kaupunkitilassa. Samalla se on myös esimerkki siitä, miten joulusesonkiin voidaan suhtautua mahdollisuutena huumoriin ja hupsutteluun. Kauppakeskusten vessoissa soiva jouluinen taustamusiikki herätti hämmennystä myös itsessäni. Koin, että "tavan taustamusiikki" eli joulusesongin ulkopuolella tilassa soiva taustamusiikki oli huomattavasti vähemmän häiritsevää. Tulkitsen, että tämä johtuu joulumusiikin uskonnollisesta merkityksestä.

Aineistonkeruun edetessä alkuperäinen suunnitelmani rajata huomio vain äänitteisiin sekä julkiseen ja kaupalliseen tilaan alkoi näyttäytyä koko aineiston valossa pakotetulta rajaukselta. Tähän suurimpana syynä on verkon eli virtuaalisen kaupallisen tilan vahva läsnäolo arjessa. Shoppailun laajeneminen julkisesta kaupankäynnille osoitetusta tilasta jokapaikkaiseksi on muokannut kuluttajan arkista tilaa (Vakimo 2017, 2), myös äänimaisemallisesti. Aineistoa uudelleenlukiessani näyttää, että kaupallinen tila äänimaiseman kuulokulmasta on siellä missä äänimainontaa kuulee. Tietokoneiden, digiboksien ja mobiililaitteiden audiovisuaalisessa ympäristössä joulun "helinä" on ensisijaisen tunnusomaista. Esimerkkinä tästä nostan sosiaalisen median mainosvirran kännykän selainta käytettäessä. Syötevirrassani 
juoksi useita mainoksia, jotka olivat osa laajempia joulusesonkikampanjoita ja olivat ääniraidaltaan myös televisiomainoksista tuttuja. Kyseinen esimerkki alla on Saarioisen pakastetaikina- tai hillomainos (ks. kuva 4). 15 sekunnin mainoksessa kuului ponnahtelevia jousia, kellopelimelodia, joka oli kerrottu sahamaisella ulinalla sekä tyrskähteleviä harppu-arpeggioita. Mielleyhtymäni musiikista oli fantasiaelokuvamainen. Musiikilla leivottu jouluntaika kuvasi mielessäni tunnelmaa satuolentojen joulupöydässä.

Yksi ilmoittaja lähetti kokemuksensa YouTube-soittovirrasta. Sivustolla on oletusarvona toiminto, joka jatkaa videoiden automatisoitua soittoa oman algoritmisen logiikkansa mukaan, soittamalla videoiden väliin myös mainoksia. Ilmoittaja vertasi kokemusta "isoon tavarataloon jossain isossa kaupungissa. Oikeasti hetki sitten oli eka kerta [16.12.], kun joulumusaa tarjoutui kuultavaksi". Myös omissa muistiinpanoissani on maininta YouTube-mainoksista. Mainoksen

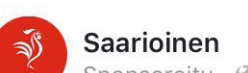
Sponsoroitu.

Paista ja maista pullean pekonista omenakanelipossua.

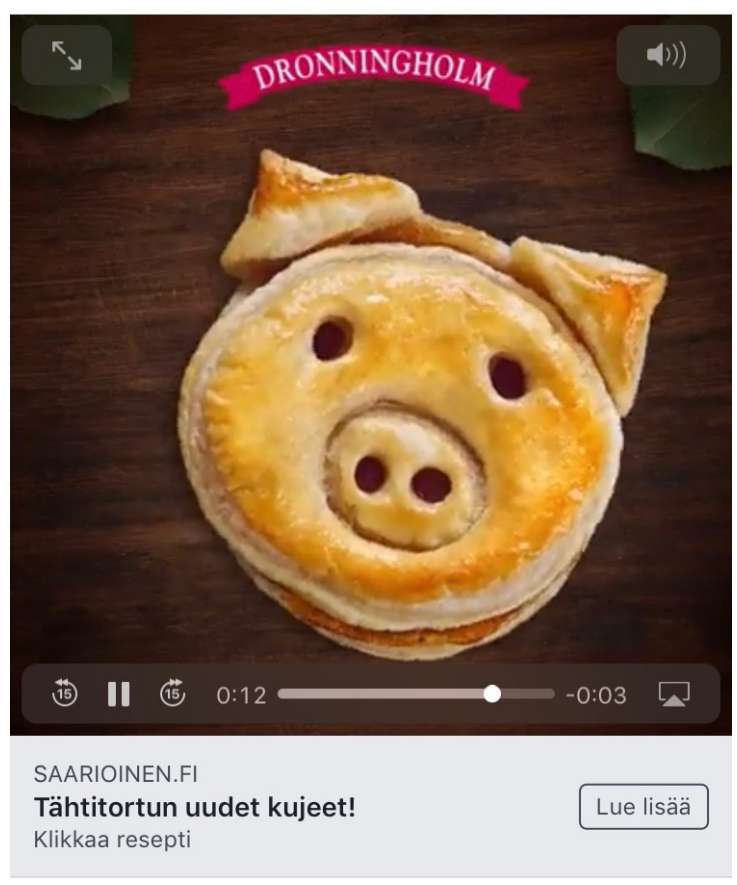

Kuva 4: Kuvakaappaus Saarioisen

Facebook-mainosvideosta.

aihetta en pannut merkille, koska tuijotin viiden sekunnin laskuria, jonka jälkeen mainoksen saattoi klikkaamalla ohittaa. Musiikki koostui leveästä jousimatosta, rekikelloista ja kellopelistä. Melodiaa en tunnistanut, mutta se tuntui kelluvan tasaisen rytmin päällä. Näissä mainosten taustamusiikeissa jouluisiksi tunnistettujen musiikillisten elementtien, kuten metallisen helinän kuuluminen, on ratkaisevaa.

Samantyylisestä joulukoristellusta taustamusiikkista tein muistiinpanot Tampereen rautatieasemalla, S-marketissa. Puhemainoksessa miesääni kertoi, että:

"Satokausituotteilla loihdit sekä perinteisen että vegemmän version. Valmista härkiskäristystä selleri-omenapyreen kera. Ohjeet jouluisiin herkkuihin löydät Yhteishyvän sesonkilehdestä, ja nyt, mars hedelmä- ja vihannesosastolle." (19.12.2019 ACMESOCS-JouluA 2020)

Tämän mainoksen taustalla oli tasainen rekikellorytmi, putkikelloja ja lopussa puheen päätyttyä sähkökitaramelodia, jonka tunnistin S-ryhmän jingleksi. Tämä pienmuotoinen käyttömusiikin (ks. Kilpiö 2005) esimerkki kuului hädin tuskin kassalaitteiden viivakoodien piippausten, ilmastoinnin huminan, kylmälaitteiden hurinan ja puuroutuneen puheensorinan alta. Lopuksi kuului ja tuntui jalanpohjissa runkoäänenä ohittavan junan tärinä.

\section{Pohdinta: jouluinen taustamusiikki kalendaarisena koristeluna}

Kalendaarisuus ilmenee äänimaisemassa musiikillisena koristeluna. Joulun musiikilliset koristeet ilmenevät paitsi jokapaikkaisessa taustamusiikissa myös joulun tunnelmaan ja joulun taikaan liitetyssä metallisointisessa helinässä. Lähtökohtani oli tutkia Kari Korolaisen 
(2012) ajatusta koristelun vuodenkierrosta soveltaen sitä äänimaisemaan ja joulusesonkiin. Tavan taustamusiikiksi kutsumani tilaan valittu joulusesongin ulkopuolella soiva musiikki on visuaaliseen koristeluun verrattuna "kiinteää koristelua" ja joulutaustamusiikki puolestaan "juhlakoristelua" (vrt. Korolainen 2012, 46, 67). Tavan taustamusiikki on sisustamista, äänellä tapetointia (muiden äänellisten elementtien peittämistä) ja tunnelman luomista. Joulutaustamusiikki on juhlatunnelman rakentamista irrallisen koristelun kaltaisesti, musiikillisia elementtejä lisäämällä. Joulumusiikki kaupungissa on visuaalisten koristeiden kaltainen elementti, jossa arvokkuus ja perinne yhdistyy krääsään ja liiallisuuksiin.

Kaupungilla koristellaan musiikilla monia tiloja joulusesonkina rituaalinomaisesti.Tunnelmaa rakennetaan pienimuotoisemmin uimahalleissa, takseissa ja huoltoasemilla, ja suurmittaisesti kokonaisilla jouluesineosastoilla tavarataloissa, joissa musiikki myös soi suurempana, kovemmalla volyymilla. Tällä koristelulla rakennetaan myös tunnelmaa joulumatkailun tarpeisiin. Joulun perinteeseen liittyvä musisointi niveltyy lähes saumattomasti funktionaalisen musiikin tiloihin, jumppatunnille ja lentoasemalle. Kaupungilla kuultavaan joulumusiikkiin vaikuttaa myös vahvasti toreilla, kaupoissa ja kahviloissa käytettävissä olevat teknologiset apparaatit, jotka eivät aina ole äänentoistollisesti laadukkaita tai sijoittelultaan mietittyjä. Pikkukaiuttimet toistavat parhaiten korkeita äänentaajuuksia, jolloin helisevät äänet korostuvat. Väliaikaiset kaiutinjärjestelmät tavaratalojen jouluikkunoiden edessä ja joulutorien taustamusiikki tuovat taustamusiikkia paikkoihin, joissa niitä ei muutoin ole. Tämä saa kiinnittämään niihin hetkellisesti enemmän huomiota, kimmeltävän koristeen tavoin.

Aineiston kokonaisuutta analysoitaessa on otettava huomioon se tärkeä seikka, että kukaan ilmoittaja ei ilmoittanut toimivansa eikä tietääkseni toiminut keruuaikana palvelualalla. Tuntimäärällisesti eniten taustamusiikkia kuulevat kauppojen myyjät, ravintoloiden tarjoilijat ja hotellien vastaanottovirkailijat. Kun palvelualan työntekijöiltä kysyttiin tutkimushankkeen toisessa osuudessa taustamusiikin sesongeista, mainitaan joulumusiikki sekä hyvässä että pahassa (ACMESOCS-PAM 2021). Toisaalta "hyvä joulumusiikki" lisää viihtyvyyttä ja on "kivaa vaihtelua". Joskus sesonkia ei maltettaisi olla aloittamatta, mutta työkaverien vuoksi sinnitellään, kuten eräs myyjä asian ilmaisee:

"Lokakuussa alkaa pienimuotoinen taistelu, kun minä ja muutama muu olisimme jo valmiit siirtymään joulumusiikkiin, mutta muiden mielestä on vielä aivan liian aikaista". (ACMESOCS-PAM 2021, 630)

Toisaalta työnteko joulumusiikin keskellä koetaan rasitteeksi, joka kestää kohtuuttoman pitkään. Ärsyyntyminen johtuu usein liian lyhyestä soittolistasta, josta johtuu kappaleiden toisteisuus. Tämä johtaa yhdellä vastaajalla siihen, että hän ei halua kotona kuunnella joulumusiikkia laisinkaan, "tai yleensä mitään musiikkia". (ACMESOCS-PAM 2021). Tällaisessa tilanteessa liiallinen musiikilla koristelu saa aikaan vakavaa vastenmielisyyden kokemusta.

Kaupallisessa tilassa kuuluva joulumusiikki on sekoitus perinnemusiikkia ja taloudellisen hyödyn logiikkaa. Tekijänoikeusvapaat kappaleet ovat suosittuja levytettäviä ja niitä myös kuulee siksi paljon. Esimerkiksi Franz Gruberin kappaletta "Stille nacht, heilige nacht" vuodelta 1818 löytyy Spotifyn 1,3 miljoonan joululaulun tarjottimelta yli 26000 englanninkielistä versiota (ks. Hickey 2015), suomenkielisiä versioita löytyy noin 250 . Tämän tutkimuksen aineistossa kappaleen versioita on kuusi. Toisteisuus on vaikuttava tekijä tuttuuden 
tuotannossa ja tekee kappaleista taustamusiikkiyhteydessä enemmän kliseen kaltaisia kuin arvokkaaksi koetun musiikillisen perinteen jatkajia.

Koronapandemian aiheuttama poikkeus joulunvietossa vuonna 2020 kuului omien huomioideni mukaan äänimaisemassa pääosin kaupallisen tilan ja musisoinnin siirtymisenä vahvemmin kotitilaan. Joulumusiikin välttelyleikki onnistui monelta helpommin, koska ostoksia tehtiin enemmän verkossa, eikä kaupungilla liikuttu yhtä paljon kuin tavallisena jouluna. Twitterissä kommentoitiin jouluna 2020 aihetunnisteella \#loirigeddon samansuuntaisesti:

\footnotetext{
"Näin koronafi\# aikaan kun on käytännössä vain kotona eikä kauppakeskuksissa, on aika paljon helpompaa pärjätä \#whamageddon'issa ja \#loirigeddoni'issa. Radio on ehkä suurin riski. Enää kaksi viikkoa \#joulu'un!" (10.12.2020)

"Selvisin \#whamageddon2020 [ei] yllättänyt edes \#Loirigeddon. Olen selkeästi voittajaluonne. Asiaa auttaa se, etten kuuntele radiota ja teen ostokset verkossa. Työmatkallakin tulee kuunneltua vain äänikirjoja." (23.12. 2020)
}

Jouluradio pyrki jatkamaan elävän musiikin konserttilähetyksiään samalla noudattaen vallitsevia kokoontumis- ja esiintymisrajoituksia. Keinoksi valittiin maailman kaupungeista uutisoitu ja pandemian aikana suosituksi tullut parvekkeilla laulaminen (ks. kuva 5).

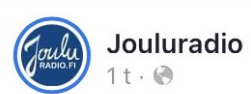

Parvekejoululauluna kuullaan tänään klo 15 En etsi valtaa loistoa Polyteknikkojen kuoron esittämänä. Laulu tulee myös Jouluradiosta kolmen hujakoilla. Oletko mukana? \#parvekejoululaulut \#kuuluujouluun \#jouluradio

- Katri

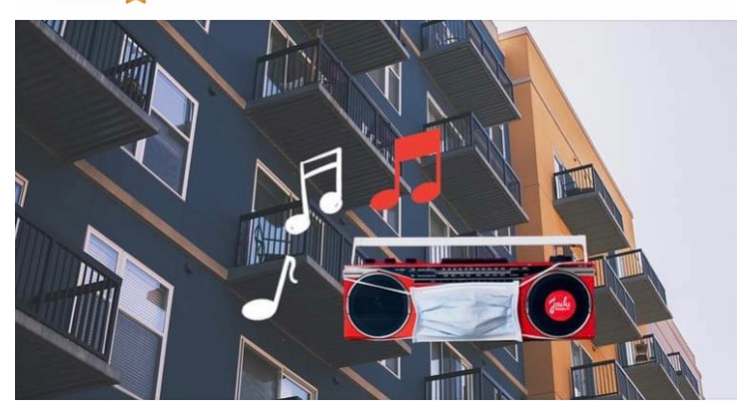

Kuva 5: Kuvakaappaus Jouluradion Facebooksivulta jouluna 2020, jossa mainostetaan Polyteknikkojen kuoron parvekejoululaululähetystä. Kuvassa on punainen radio puettuna hengityssuojaimeen, nuotteja ja taustalla kerrostalo parvekkeineen. kin kaupunkilaisena. Tämä näkökulma laajentaa taustamusiikin kokemuksen käsitteellistämistä, koska jokapaikkaisena musiikkina se ei rajaudu asiakkuustilanteisiin tai kuluttamiseen. Aineistosta esille nostamani neljä teemaa tuovat esille taustamusiikin kontekstisidonnaisia ja ajallisia ominaisuuksia. Kokemus jouluiseen musiikkiin törmäämisestä ja tarttuvuudesta 
ennakoi sesongin alkamista. Sesonki ymmärretään alkamisen, täyden tunnelman ja loppumisen kaarena, jonka aikana sitä kohti voidaan hakeutua tai sitä voidaan vältellä leikkisästi sosiaalisessa mediassa kommentoiden. Tärkeää on huomata jouluisen musiikin tilallinen jokapaikkaisuus, joka korostuu digitaalisen kaupallisen tilan levitessä kotitilaan.

Taustamusiikki kuuluu tilassa ympäröivänä ja pääosin hiljaisella volyymilla, jolloin musiikillisia elementtejä hädin tuskin kuulee muun äänimaiseman läpi. Kappaleet toistuvat ja niitä voi jopa tiettyyn pisteeseen asti ennakoida. Kappaleita ei kuitenkaan usein kuule alusta loppuun, vaan melodioita sieltä, toisen täältä, kunnes on aika astua ulos ratikasta, edetä jonossa kassalle, keskustella pöytäseurueen kanssa tai vaihtaa laitetta kuntosalilla. Kaupungilla liikkuminen vaikuttaa kuunteluun siten, että musiikkeja kuullaan päällekkäin ja äänen lähde jää epämääräiseksi. Kirkkaana tästä erottuvat joulusesonkina kuitenkin metalliset helinät.

Kuulija on liikkeessä. Hänen kokemuksensa taustamusiikista on limittyvien äänilähteiden kuuntelua, voimistuvien ja heikentyvien musiikillisten elementtien havaitsemista ja läpikävelemistä, hetkittäin ja sattumanvaraisesti. Tästä johtuu myös esittelemässäni aineistossa ilmenevä tietty varovaisuus ja havaintojen tapailu, kun pyysin ilmoittamaan kuultua musiikkia, tunnistetusta musiikista puhumattakaan. Sama havaintojen tapailu toistuu omissa äänipäiväkirjamerkinnöissäni. Ymmärrän tämän pysyväksi piirteeksi sellaisissa aistietnografisissa aineistoissa, jotka kuvaavat arjen ääniympäristöjen kokemista. Kokeilemalla äänitilan havainnoinnin talkoistetun keruun menetelmää tunnistamisen kynnys madaltuu ja havaintoja voi välittää pienimuotoisesti, havainnon mittakaavaan nähden sopusuhtaisella tavalla.

Kaupunkien aistiympäristöjen muutosta teoretisoinut Jean-Paul Thibaud (2020) haluaa kiinnittää huomiota moniaististen mainostumisen prosessien sijaan tunnelman aistimisen herkkyyteen (engl. "ambient sensitivity"), jossa korostuu minkä tahansa aistikokemuksen hajanainen, affektiivinen ja läpäisevä luonne. Thibaud painottaa tällaisen herkkyyden voimaa vahvistaa ja muuttaa suhteitamme maailmaan. Kuten monet kulttuurisesti aistikokemusta teoretisoivat, Thibaud haluaa lisätä subjektin toimijuutta aistikokemustensa omistajana ja niistä tietävänä. Tämä on ollut päämääräni myös tässä tutkimuksessa, jossa olen halunnut osoittaa, miten arkinen kokemus taustamusiikin ohikuulemisesta on monipuolisempaa ja monivivahteikkaampaa kuin taustamusiikkituotteita myyvät ja niitä tilaavat antavat ymmärtää.

\section{Tutkimusaineistot}

ACMESOCS-JouluA. 2020. Kuultu joulumusiikki kaupunkiympäristössä, autoetnografinen kenttäaineisto 1.11.2019-10.1.2020. Aineisto tutkimushankkeen hallussa.

ACMESOCS-JouluB. 2020. Kuultu joulumusiikki kaupunkiympäristössä, kuulohavaintojen keruuaineisto 1.11.2019-10.1.2020. 54 Facebook-päivitystä, 27 Messenger-viestiä, 19 WhatsApp-viestiä, 14 Twitter-päivitystä. Aineisto tutkimushankkeen hallussa.

ACMESOCS-PAM 2021. Taustamusiikkia työpaikalla. Webropol-alustalla toteutettu verkkokysely palvelualan työntekijöille 26.1.-20.5.2021. 747 vastausta. Aineisto tutkimushankkeen hallussa.

GT Musiikkiluvat 2020. "Onnistu joulumusiikinvalinnassa". Luettu 11.11.2020. https://www. musiikkiluvat.fi/kuulokanavalla/onnistu-joulumusiikin-valinnassa/ 
Hickey, Walt. 2015. "The most-covered Christmas songs ever". Luettu 31.12.2021. https:// fivethirtyeight.com/features/the-most-covered-christmas-songs-ever/

Joululaulubingo 2019. Julkinen tutkimuspäiväkirja joulumusiikista kaupunkiympäristössä. Luettu 31.12.2021. https://merikyto.net/category/joululaulubingo/

Joululaulubingo Spotify 2019. Soittolista aineistossa kuulluista jouluisista taustamusiikkikappaleista. Luettu 31.12.2021. https://open.spotify.com/ playlist/6wj6lel3ultAvIBXIjFWTV.

\section{Kirjallisuus}

Belk, Russel W. 1993. "Materialism and the Making of the Modern American Christmas." Teoksessa Unwrapping Christmas, toimittanut Daniel Miller, 75-105. Oxford: Claredon Press.

Decker, Todd. 2020. "Carols and Music Since 1900." Teoksessa The Oxford Handbook of Christmas, toimittanut Timothy Larsen, 330-345. Lontoo ja New York: Oxford University Press. https://doi.org/10.1093/oxfordhb/9780198831464.013.28.

DeNora, Tia. 2000. Music in Everyday Life. Cambridge: Cambridge University Press. https://doi. org/10.1017/CBO9780511675850.

Highmore, Ben. 2002. Everyday Life and Cultural Theory: an Introduction. London: Routledge. https://doi.org/10.4324/9780203464229.

Gramex avoimuusraportti 2019. "Avoimuusraportti." Luettu 6.8.2021. https://www.gramex.fi/ wp-content/uploads/2018/10/Avoimuusraportti-yhdistyksen-kokouksen-käsittelyyn-2. pdf.

Gramex 2020. "Sydämeeni joulun teen radioiden soitetuin kotimainen joululaulu." Luettu 6.8.2021. https://www.gramex.fi/sydameeni-joulun-teen-radioiden-soitetuinkotimainen $/ 3254 /$.

Jaakkola, Kaisu. 1977. Muuttuva joulu. Kansatieteellinen tutkimus. Helsinki: Suomen Muinaismuistoyhdistys.

Jarman-Ivens, Freya. 2008. "The musical underbelly of christmas." Teoksessa Christmas, Ideology and Popular Culture, toimittanut Sheila Whiteley, 113-134. Edinburgh: Edinburgh University Press.

Järviluoma, Helmi, Ari Koivumäki, Meri Kytö ja Heikki Uimonen, Heikki (toim.). 2006. Sata suomalaista äänimaisemaa. Helsinki: Suomalaisen Kirjallisuuden Seura.

Järviluoma, Helmi, Meri Kytö, Barry Truax, Heikki Uimonen ja Noora Vikman (toim). 2009. Acoustic Environments in Change \& Five Village Soundscapes. Tampere ja Joensuu: TAMK University of Applied Sciences \& University of Joensuu.

Kurjenoja, Jaana. 2019. "Kaupan suurin sesonki: joulu." Luettu 31.12.2021. https://kauppa.fi/ palvelut-ja-tietopankki/tutkimukset-ja-tilastot/muut-tutkimukset/.

Kilpiö, Kaarina. 2005. Kulutuksen sävel: suomalaisen mainoselokuvan musiikki 1950-luvulta 1970-luvulle. Helsinki: Like.

Kilpiö, Kaarina. 2011. "Alitajunnan ohjailemisesta profiloitumiseen: taustamusiikkituotteiden muutoksia 1900-luvun Suomessa." Musiikin suunta 33(2): 11-17.

Kurkela, Vesa. (1999) 2019. "1800-luvun sointikuva ja populaarimusiikki. Lähtökohtia varhaisen populaarimusiikin soinnin tutkimiseen". Etnomusikologian vuosikirja 31: 143166. https://doi.org/10.23985/evk.86179.

Korolainen, Kari. 2012. Koristelun kuvailu. Kategorisoinnin analyysi. Joensuu: Itä-Suomen yliopisto. 
Kytö, Meri. 2011. "Moderni kaupunkilaisuus akustisena järjestyksenä - Istanbulilaisen taloyhtiön äänimaisemaetnografia." Etnomusikologian vuosikirja 23: 114-139. https:// doi.org/10.23985/evk.66822

Leigh-Choate, Tova. 2020. "Carols and Music to 1900." Teoksessa The Oxford Handbook of Christmas, toimittanut Timothy Larsen, 312-327. Lontoo ja New York: Oxford University Press. https://doi.org/ 10.1093/oxfordhb/9780198831464.013.27.

Malmelin, Nando. 2003. Mainonnan lukutaito. Mainonnan viestinnällistä luonnetta ymmärtämässä. Helsinki: Gaudeamus.

Mäkinen, Timo. 1968. Piae cantiones -sävelmien lähdetutkimuksia. Acta musicologica Fennica, 1. Helsinki: Suomen Musiikkitieteellinen Seura.

Pajamo, Reijo ja Erkki Tuppurainen. 2004. Kirkkomusiikki. Suomen musiikin historia. Helsinki: WSOY.

Pöysä, Jyrki. 2015. Lähiluvun tieto. Näkökulmia kirjoitetun muistelukerronnan tutkimukseen. Vantaa: Suomen Kansantietouden Tutkijain Seura, Kultaneito XVII.

Schmalzbauer, John. 2020. "Commercialism and Consumerism." Teoksessa The Oxford Handbook of Christmas, toimittanut Timothy Larsen, 550-558. Lontoo ja New York: Oxford University Press. https://doi.org/ 10.1093/oxfordhb/9780198831464.013.44.

Small, Christopher. 1998. Musicking: The Meanings of Performing and Listening. Connecticut: Wesleyan University Press.

Stockfelt, Ola. 1994. "Cars, Buildings and Soundscapes." Teoksessa Soundscapes. Essays on Vroom and Moo, toimittanut Helmi Järviluoma, 19-38. Tampere: University of Tampere.

Studwell, William. 2011. The Christmas Carol Reader. Lontoo ja New York: Routledge.

Teosto avoimuusraportti 2020. "Avoimuusraportti." Luettu 6.8.2021. https://www.teosto.fi/ app/uploads/2021/05/11154228/teosto avoimuusraportti-tilinpaatos 2020 fi final. pdf

Thibaud, Jean-Paul. 2011. "A Sonic Paradigm of Urban Ambiances." Journal of Sonic Studies 1(1). https://www.researchcatalogue.net/view/220589/220590.

Thibaud, Jean-Paul. 2020. "The Hypothesis of Ambient Sensitivity." Kutsuttu luento konferenssissa Urban-Related Sensoria: Environments, Technologies, Sensobiographies, 12.6.2020, Itä-Suomen yliopisto.

Truax, Barry. 2001. Acoustic communication. Second edition. Westport, Connecticut: Ablex publishing.

Uimonen, Heikki. 1999. "Radio työpaikan äänimaisemassa." Etnomusikologian vuosikirja 11: 118-133. https://doi.org/10.23985/evk.101100.

Uimonen, Heikki, Meri Kytö ja Kaisa Ruohonen (toim.). 2017. Muuttuvat suomalaiset äänimaisemat. Tampere: Tampere University Press. http://urn.fi/ URN:ISBN:978-952-03-0382-2

Uimonen, Heikki ja Meri Kytö. 2020. "Toimimatonta tekniikkaa ja alitajuista vaikuttamista. Etnomusikologinen näkökulma taustamusiikin tutkimukseen." Etnomusikologian vuosikirja 32: 45-75. https://doi.org/10.23985/evk.90066.

Uimonen, Heikki. 2021. "Kaupunkitila päivittäismusiikin aikakaudella: ääniympäristön tutkimuksen teoreettinen ja metodologinen tarkastelu." Teoksessa Humanistinen kaupunkitutkimus, toimittaneet Tanja Vahtikari, Terhi Ainiala, Aura Kivilaakso, Pia Olsson, ja Panu Savolainen, 145-167. Tampere: Vastapaino.

Uotinen, Johanna. 2010. "Kokemuksia autoetnografiasta." Teoksessa Vaeltavat metodit, toimittaneet Jyrki Pöysä, Helmi Järviluoma ja Sinikka Vakimo, 178-189. Joensuu: Suomen Kansantietouden Tutkijain Seura. 
Vakimo, Sinikka. 2017. '"Arvostan rehellistä ja molempia tyydyttävää kaupankäyntiä': Etnografinen tutkimus verkkovertaiskaupan käytännöistä ja moraalista". Elore 24(2): 1-31. https://doi.org/10.30666/elore.79298

Vikman, Noora. 2007. Eletty ääniympäristö. Pohjoisitalialaisen Cembran kylän kuulokulmat muutoksessa. Tampere:Tampereen yliopisto. http://urn.fi/urn:isbn:978-951-44-7126-1

Meri Kytö on filosofian tohtori ja kulttuurisen musiikintutkimuksen (erit. kulttuurisen äänentutkimuksen) dosentti Itä-Suomen yliopistossa. Hän toimii yliopistotutkijana Suomen Akatemian rahoittamassa Kuuntelun kulttuurit, medioidut äänet ja rakennetut tilat -hankkeessa (ACMESOCS). Häntä kiinnostaa äänellinen kaupunkitila, siinä tapahtuvat merkityksenannot ja teknologian läsnäolo. 